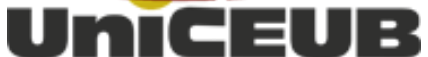 \\ Centro Unıversitárıo de Brasílıa \\ CENTRO UNIVERSITÁRIO DE BRASÍLIA - UniCEUB FACULDADE DE CIÊNCIAS JURÍDICAS E SOCIAIS - FAJS PROGRAMA DE INICIAÇÃO CIENTÍFICA
}

JOVELINA BARROS PISCO

LIBERDADE, POLÍTICA E ECONOMIA: UMA LEITURA DA CONJUNTURA BRASILEIRA ATUAL À LUZ DO LIBERTARIANISMO 


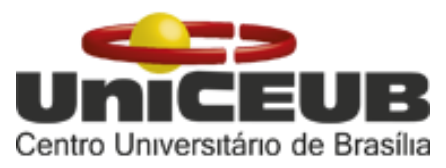

JOVELINA BARROS PISCO

\section{LIBERDADE, POLÍTICA E ECONOMIA: UMA LEITURA DA CONJUNTURA BRASILEIRA ATUAL À LUZ DO LIBERTARIANISMO}

Relatório final de pesquisa de Iniciação Científica apresentado à Assessoria de Pós-Graduação e Pesquisa pela Faculdade de Ciências Jurídicas e Sociais.

Orientação: Martin Adamec 
Agradecimento,

Ao professor Dr. Martin Adamec pela orientação e infinita paciência. 
Eu teria, creio, amado a liberdade em todos os tempos; mas sinto-me inclinado a adorála nos tempos em que estamos.

Alexis de Tocqueville 


\section{Liberdade, política e economia: uma leitura da conjuntura brasileira atual à luz do libertarianismo}

\section{Jovelina Barros Pisco - UniCEUB, PIBIC-CNPq, aluno bolsista linabrrs@gmail.com}

\section{Martin Adamec - UniCEUB, professor orientador martin.adamec@uniceub.br}

A presente pesquisa buscou compreender o desenvolvimento do libertarianismo enquanto ideologia, e de que meios e modos esta penetra na organização social e na formação dos discursos políticos em voga, buscando, ao fim, apreender a aplicação dessa ideologia ao cenário político brasileiro nos últimos anos. Para tal, em primeiro lugar, discutiu o conceito de ideologia, tida aqui como algo essencialmente positivo e necessário à vida social, em especial no campo político, partindo do pressuposto de que surge não apesar do homem ser racional, mas porque ele é racional, ou seja, como uma representação coerente de determinado contexto. Em seguida, abordou a ideologia libertária no que diz respeito a suas origens no liberalismo clássico, focando o conceito de liberdade, elemento fulcral de ambas as ideologias em pauta. Trata-se, aqui, fundamentalmente, da liberdade individual, alçada no princípio da não-agressão, da valorização da propriedade privada e da supremacia do indivíduo, onde o papel do governo seria apenas o de garantir o respeito a esses pressupostos e a segurança da sociedade. Neste âmbito, foi feita uma abordagem de tipo qualitativo, mediante revisão bibliográfica de fontes primárias e secundárias, valendo-se de teóricos como John Locke, Murray Rothbard, Milton Friedman e David Boaz. Ato contínuo, a pesquisa empreendeu uma contextualização histórica das ideologias políticas do século $\mathrm{XX}$, de modo que fosse possível compreender as influências que marcaram profundamente a organização civil atual, possibilitando a concepção e implementação do libertarianismo. Este, para os fins da presente pesquisa, foi analisado como uma nova ideologia em favor da liberdade, dissociada, em termos teóricos, das premissas liberais anteriores e suas simplificações e, em termos práticos, das políticas do Estado de bem-estar social e derivados. Por fim, concatenou os conceitos previamente analisados com o cenário político-social brasileiro, levando-se em consideração a apropriação do discurso libertário no cenário nacional e sua conexão com as manifestações que ocorreram em 2013, bem como o surgimento de movimentos e partidos políticos que, embora não se declarem libertários, compactuam com os ideais defendidos, 
seja como uma filosofia voltada à organização econômica e limitação do Estado, seja também, e principalmente, como uma doutrina que advoga em prol da autonomia do indivíduo e de sua liberdade, seja ela civil, política ou econômica.

Palavras-chave: Libertarianismo. Liberalismo. Estado de bem-estar social. Economia livre. Ideologia. 
SUMÁRIO

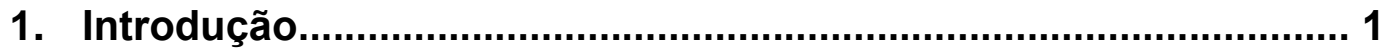

2. Fundamentação Teórica............................................................... 3

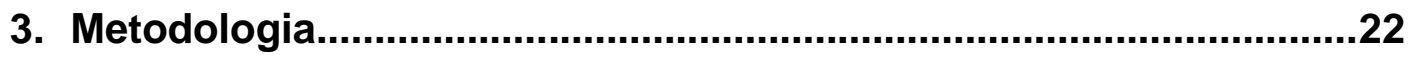

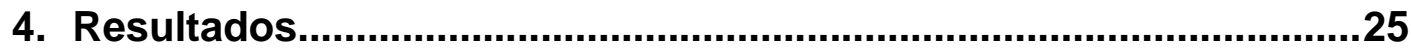

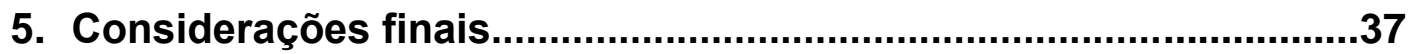

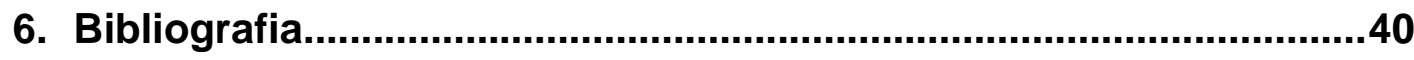




\section{INTRODUÇÃO}

O presente trabalho busca analisar a atual conjuntura política brasileira sob a ótica da ideologia libertária, e sob que circunstância esta se tornaria uma possível resposta às insatisfações sociais e econômicas recentes, perceptíveis pelas manifestações maciças contra o governo desde junho de 2013.

De acordo com a perspectiva libertária atual, libertarianismo é a filosofia política que defende que cada pessoa tem o direito de viver a sua vida conforme escolher, desde que respeite a igualdade de direitos dos outros, assim como seu direito à vida, liberdade e propriedade (BOAZ, 1998). Nesse contexto, o governo só deve intervir para a proteção e defesa desses valores, e todas as relações humanas devem ser voluntárias.

Posto isso, nota-se que tais premissas não eram tão discutidas como agora, especialmente no Brasil, de modo que este trabalho visa a analisar o porquê da crescente relevância e fortalecimento da perspectiva libertária no Brasil nesse contexto específico, levando-se em conta as especificidades do ambiente em que se insere. Nesse sentido, uma das questões a serem analisadas inquire quais, exatamente, foram as medidas ou circunstâncias na esfera político-econômica que inquietaram a população brasileira e porque mais liberdades e um Estado mínimo podem ser uma resposta a esses problemas.

O primeiro impulso para tal análise foi uma aparente maior disseminação e influência da perspectiva libertária no cenário brasileiro atual, como visto, por exemplo, na atuação de forças políticas como o Partido NOVO e o Movimento Brasil Livre. Portanto, a proposta inicial é estabelecer um diálogo entre teoria e prática, entre a referida perspectiva libertária e a realidade brasileira contemporânea. Com tal propósito, busca-se apreender um conceito mais ou menos homogêneo do termo libertarianismo e delimitá-lo conforme suas teses e aplicações práticas, tendo sempre como norte o impacto de tal ideia no cenário político-econômico nacional.

Desta feita, em se tratando de Brasil, optou-se pelo Plano Real como marco temporal inicial, passando pela configuração econômica brasileira a partir de meados da década de 90, sob o governo de Fernando Henrique Cardoso, e seu contraste com as modificações político-econômicas até os dias atuais, percebendo, inclusive, as influências patentes do patrimonialismo entranhado na formação do Estado brasileiro. 
Assim, o presente trabalho busca identificar e analisar fatores específicos, passíveis de gerar uma resposta de cunho libertário no cenário brasileiro atual, assim como investigar o quanto dessa ideologia integra os partidos e movimentos que se propõem a defendê-la.

Com base nisso, o escopo da pesquisa em pauta é a concatenação de objetivos que seguem uma lógica histórica e cronológica, partindo da evolução do libertarianismo como perspectiva que interliga os campos da teoria do Estado, filosofia e economia, desde suas origens no liberalismo clássico de John Locke, passando por algumas escolas mais ou menos teóricas, especialmente o utilitarismo, o objetivismo e a escola austríaca.

Ato contínuo, analisa a evolução do cenário político-econômico brasileiro nos últimos vinte anos, desde a instauração do Plano Real à influência de determinadas ideias, que guardam relação direta com o cenário de crise e revolta atual, criando, inclusive, um terreno fértil para o surgimento de movimentos de natureza libertária.

Por fim, pode-se pontuar duas hipóteses básicas a nortear este trabalho, quais sejam, o contexto social e econômico brasileiro nos últimos vinte anos aparece como ambiente propício ao surgimento de uma resposta libertária na sociedade; e que os partidos e movimentos políticos, assim como algumas figuras específicas, surgiram e galgaram relevância política em tempos recentes baseados em premissas libertárias, ainda que modificadas para sua aplicação na conjuntura brasileira. 


\section{FUNDAMENTAÇÃO TEÓRICA}

O trabalho objeto deste relatório empreendeu um estudo sobre a ideologia libertária, desde suas origens no liberalismo clássico de John Locke e na separação de poderes de Montesquieu, até, primordialmente, sua inserção no cenário brasileiro, cuja formação se deu de modo peculiar e, por vezes, antagônico às expectativas e premissas dessa corrente ideológica.

Ao pensarmos a vida em sociedade, em particular na esfera política, a multiplicidade de ideias envolvidas comporta extensa disputa. Se por um lado, essa variedade de visões de mundo incentiva um debate mais rico, por outro lado traz consigo uma medida de intolerância para que uma se sobressaia à outra. Essa heterogeneidade está entranhada na própria ciência das ideias, a ideologia, que por compreender significados distintos, termina por ser um conceito vago em discussões.

Apesar de extremamente laborioso descrever uma hegemonia conceitual a respeito do termo ideologia, ao tratarmos aqui do libertarianismo como tal, é mister a explanação, ainda que superficial, da história da ideologia enquanto conceito, e qual abordagem dela será adotada neste trabalho. Para tanto, seguiremos examinando, essencialmente, o conceito de ideologia utilizado no cotidiano, em comparação à definição de pensadores e teóricos das mais variadas vertentes, ainda que contraditórias entre si, com intuito de fazer um apanhado geral das principais correntes críticas a respeito da ideologia e explicitar qual e porque será o conceito utilizado.

De acordo com o dicionário Aurélio ${ }^{1}$ de língua portuguesa, temos a ideologia como 1 Ciência da formação das ideias; 2 Tratado sobre as faculdades intelectuais; 3 Conjunto de ideias, convicções e princípios filosóficos, sociais, políticos que caracterizam o pensamento de um indivíduo, grupo, movimento, época, sociedade. Em outra conotação, pode-se conceituar ideologia como um sistema que considera a sensação como fonte única dos nossos conhecimentos e único princípio das nossas faculdades. ${ }^{2}$

Todavia, no campo teórico, tais conceituações assumem caráter mais subjetivo, sendo sumariamente influenciadas pelo meio, remetendo mais ainda à ideologização do próprio termo. A palavra ideologia, em respeito à ordem

\footnotetext{
${ }^{1} \mathrm{http} / / / \mathrm{www}$.dicionariodoaurelio.com/ideologia

${ }^{2}$ http://michaelis.uol.com.br/moderno/portugues/index.php?lingua=portugues-portugues\&palavra=ideologia
} 
cronológica de seu desenvolvimento, foi primeiramente utilizada por Destutt de Tracy, um filósofo francês educado no iluminismo, para caracterizar uma ciência baseada na análise das ideias e sensações. ${ }^{3}$ Nada obstante, o vocábulo passou a representar uma espécie de falsa consciência, como visto em Karl Marx, onde o conceito é tido como uma forma de falsear a realidade, especialmente no que concerne à compreensão de conflitos sociais, assumindo aqui um caráter mais absoluto. ${ }^{4}$ Numa prespectiva mais relativista, Max Weber a descreve como uma interpretação individual de mundo, justificada pela multiplicidade de valores, podendo o indivíduo optar por determinado eixo. ${ }^{5}$ Retomando alguns dos pressupostos de Marx, para Louis Althusser, a ideologia figura como uma representação da experiência social, fundamentada menos em critérios de verdade e falsidade, do que em relações inconscientes de se vincular à realidade material. ${ }^{6}$ Em cenário distinto, Clifford Geertz busca uma visão mais científica que seus predecessores, sugerindo depurar o conceito de ideologia do caráter polêmico que ela vinha tomando e admitir a função de conhecimento dela, subordinada somente à sua função prático-social. $^{7}$

Do conceito inicial formulado por De Tracy, há que se resguardar a ideia de ideologia como "positiva, útil e suscetível de exatidão rigorosa", uma vez que, enquanto ciência das ideias, seria esta a primeira ciência, e dela fluiria toda a compreensão da natureza humana, possibilitando uma reestruturação da ordem social e política fundamentada em uma moralidade firme e protegida de falhas. (THOMPSON, 1990)

Weber, ainda que relativizando a ideia final de ideologia, não abandona por completo a teoria elaborada por De Tracy, posto que também parte da premissa de que esta se mostra necessária ao convívio social, quando possibilita a opção entre diversos valores ${ }^{8}$. Entretanto, se a ideologia é uma compreensão de mundo baseada em valores sociais, a pluralidade de valores presentes na sociedade admite, necessariamente, a mesma pluralidade de ideologias, tornando problemática a possibilidade de exatidão conceitual.

\footnotetext{
${ }^{3}$ THOMPSON, John B. Ideologia e cultura moderna. Petrópilis: Editora Vozes. 1990.

${ }^{4} \mathrm{CHAUI}$, Marilena. $\mathbf{O}$ que é ideologia. Coleção Primeiros Passos. Rio de Janeiro: Editora Brasiliense. 2002.

${ }^{5}$ WEBER, Max. A ciência como vocação. 1983.

${ }^{6}$ EAGLETON, Terry. Ideologia. 2.ed. São Paulo: Editora UNESP. 1997.

${ }^{7}$ BOUDON, Raymond. A Ideologia. São Paulo: Editora Atica. 1998

${ }^{8}$ SILVA, Jose Otacílio. A Produção de ideologias políticas segundo Max Weber. Revista Ciências

Sociais em Perspectiva.. 2006.
} 
Sob a ótica conceitual do mundo pós-marxismo, segundo a análise de Boudon, persiste a ideologia inicialmente trabalhada por Marx, tida como uma manipulação das ideias subordinada às condições materiais existentes, em suma, a ideologia como produto de uma falsa representação da sociedade.

Dois autores em particular influenciam o conceito de ideologia utilizado neste trabalho, dada a aplicabilidade real de seus conceitos, que trazem consigo um diálogo produtivo à construção teórica pretendida.

De partida, temos Antonio Gramsci, cujo trabalho baseia-se na ideia de hegemonia como uma categoria mais ampla de ideologia, caracterizada pela maneira como um poder governante conquista o consentimento dos subjugados a seu domínio. ${ }^{9}$ Desta sorte, sua concepção a respeito de hegemonia consolida a perspectiva do marxismo cultural, que vê os mecanismos de veiculação cultural como determinantes para a posição da classe dominante.

Nesse contexto, para os propósitos deste trabalho, concordamos com a interpretação gramsciana ao enxergar a ideologia como um mecanismo social de se relacionar com o meio material, sem, entretanto, acatar necessariamente a noção marxista de dominação de classe.

Sob outra ótica, temos a perspectiva adotada por Louis Althusser, que trabalha a ideologia como uma representação da experiência social, fundamentada menos em critérios de verdade e falsidade, do que em relações inconscientes de se vincular à realidade material. Desta forma, tem-se um conceito de ideologia baseado em uma teoria afetiva, sem, contudo, excluir os aspectos cognitivos de sua construção. Em suma, a ideologia para Althusser "expressa uma vontade, uma esperança ou uma nostalgia, mais do que descreve uma realidade". ${ }^{10}$

Para ambos os autores citados, o Estado exerce larga influência na propagação da ideologia vigente. Para Gramsci, por meio do que nomeia de Aparelhos de Hegemonia Privada, que existem de forma mais autônoma frente ao Estado, justamente por seu caráter 'privado' e adesão voluntária. Já para Althusser, os Aparelhos Ideológicos de Estado (AIE) efetivam a difusão ideológica de forma mais coercitiva, por meio de institutos obrigatórios. Desta forma tem-se a reprodução e consolidação dos ideias dominantes por meio dos mecanismos de prática ideológica, mediante quais os dominados dão seu consentimento ao poder

\footnotetext{
${ }^{9}$ IBIDEM. pp. 105

${ }^{10}$ BOUDON, Raymond. A Ideologia. São Paulo: Editora Atica. 1998. pp. 30
} 
dominante, que então estabelece sua visão de mundo para a sociedade de modo legítimo, valendo-se de aparelhos ideológicos como a mídia, as escolas, Igreja, e aparelhos de hegemonia na esfera cível, no caso, o principal aparelho ideológico de Estado é a escola, posto que forma as forças produtivas e mantém as relações de produção requeridas pelo sistema. Em síntese, "toda ideologia tem por função (que a define) 'constituir' os indivíduos concretos em sujeitos". (ALTHUSSER, 2007).

Liberalismo

A ideologia e filosofia política conhecida como liberalismo, cujo cerne gira em torno da persecução da liberdade nas mais diversas searas da vida, não obstante a ausência de um termo inicial determinado, freqüentemente volta-se para a conceituação estudada e consolidada por diversos filósofos do século XVIII e meados do século XIX, tomando por base, não sem algumas ressalvas contextuais, os ideais propostos no século XVII por John Locke. Estes podem ser apreendidos especialmente em sua obra prima, O Segundo Tratado Sobre o Governo Civil, cuja introdução à sociedade civil cumpre transcrever:

"Se todos os homens são, como se tem dito, livres, iguais e independentes por natureza, ninguém pode ser retirado deste estado e se sujeitar ao poder político de outro sem o seu próprio consentimento. A única maneira pela qual alguém se despoja de sua liberdade natural e se coloca dentro das limitações da sociedade civil é através de acordo com outros homens para se associarem e se unirem em uma comunidade para uma vida confortável, segura e pacífica uns com os outros, desfrutando com segurança de suas propriedades e melhor protegidos contra aqueles que não são daquela comunidade. Esses homens podem agir desta forma porque isso não prejudica a liberdade dos outros, que permanecem como antes, na liberdade do estado de natureza." 11

A partir deste excerto se extrai a ideia de que todos os homens são livres para viver suas vidas conforme desejarem, desde que não interfiram no igual direito dos outros de fazerem o mesmo. Para Locke, todo homem traz consigo do estado de natureza direitos inalienáveis à vida, liberdade e propriedade que, uma vez inseridos na sociedade civil, devem ser tutelados pelo Estado. Este, por sua vez, constituído por meio do contrato social, detém o monopólio da segurança e da justiça, garantido aos cidadãos condições de exercerem seus direitos e atuando na manutenção do meio social.

${ }^{11}$ LOCKE, John. Segundo Tratado sobre o Governo Civil. 3.ed. Petrópolis: Editora Vozes, 2001. pp. 139 
Influenciado pelos ideais de Locke, especialmente no que concerne à atuação do Estado, Montesquieu trabalha suas teses no sentido de separação dos poderes políticos do mesmo, objetivando com isso sua limitação na esfera civil. Sobre isso, Milton Friedman subscreveu: "O governo é necessário para preservar a liberdade, é o instrumento pelo qual exercemos a liberdade; ao concentrar o poder nas mão dos políticos, contudo, o governo também é ameaça à liberdade."12.

Direcionado um pouco mais para a preservação da liberdade, ainda que por meios distintos aos de Locke, Montesquieu analisa, em sua obra de mesmo nome, o espírito das leis, onde enfatiza que não cabe ao Estado, por mero capricho ou interesse arbitrário, a criação das leis vigentes, mas sim contextualizá-las de acordo com a realidade social dos governados. (MONTESQUIEU, 2000)

Nesse mesmo contexto, propõe a máxima de que é necessária a contenção do poder pelo próprio poder, ideia essa que baliza sua teoria de separação dos poderes onde, como decorrência da liberdade protege o povo da tirania e, como mantenedora de tal liberdade regula a vida social, estabelecendo as normas de conduta e julgando os dissidentes.

$\mathrm{Na}$ América, mais especificamente EUA, o debate ideológico também se voltava aos ideais liberais, mais especificamente como embasamento à revolução americana, agora categorizados em conservadores liberais e radicais liberais, sendo os primeiros, mais tendentes à manutenção de um estilo de liberdade britânica, e os segundos os que rejeitavam a ideia de monarquia constitucional, clamando por independência e república, como forma de proteção aos direitos naturais que thes vinham sendo denegados. (BOAZ, 2015)

Marco histórico, a Declaração da Independência em 1776, valeu-se bastante dos teóricos europeus citados, mostrando-se, essencialmente, uma compilação das ideias de direitos naturais à vida, liberdade e propriedade, sendo a tarefa do governo proteger esses direitos. Tais ideais, a essa altura, encontravam-se tão difundidos na sociedade civil americana que Thomas Jefferson, patrono da Declaração, pontuou que os fundamentos ali elencados nada mais eram que os sentimentos da própria população, constantemente expresso em toda sua produção artística e intelectual, e agora resguardado na Declaração e, posteriormente, reafirmados na Constituição dos EUA.

${ }^{12}$ FRIEDMAN, Milton. Capitalismo e Liberdade. Rio de Janeiro: LTC Editora, 2014. pp. 3 
Nesse contexto, vemos um retorno às ideias liberais clássicas, quando em prol da ratificação da Constituição dos Estados Unidos, foram veiculados artigos políticos, posteriormente compilados na obra Os Artigos Federalistas. Aqui, percebese a valorização da liberdade, seja por meio da defesa dos direitos civis de Locke, seja por meio da separação dos poderes proposta por Montesquieu.

Quanto ao primeiro, resta visível a preservação dos direitos individuais como um todo na formação do Estado americano, em particular no que aduz Madison, de que "a diversidade das faculdades humanas, das quais se originam o direito de propriedade, não é menos um obstáculo insuperável a uma uniformidade de interesses. A proteção dessas faculdades é o primeiro objetivo do governo" ${ }^{\prime 3}$. Ao segundo, atribui-se a singular influência na sistemática de pesos e contrapesos (checks and balances), onde se busca garantir a autonomia dos poderes de Estado ao mesmo tempo em que estes se regulam, de modo a impedir que chame para si poderes demais e prejudique a república.

Outro expoente do liberalismo clássico é John Stuart Mill, cuja filosofia utilitarista, inicialmente estudada por seu pai, James Mill, e o filósofo Jeremy Bentham, tem como objeto, de forma simplificada, a máxima felicidade para o maior número de pessoas. Busca em sua obra Sobre a Liberdade uma perspectiva diferente a respeito da liberdade, agora mais voltada para a proteção frente ao meio social, não apenas estatal, onde cabe ser analisado o limite do poder que a sociedade, enquanto maioria, exerce sobre o indivíduo

Nestes termos, Mill propõe um princípio a ser observado para a preservação da liberdade no meio social, qual seja, que a proteção do outro e da sociedade como um todo é o único motivo legítimo para a interferência nas atividades do indivíduo. ${ }^{14}$

Em suma, tem-se, ainda, a ideia de liberalismo no século XIX consubstanciada nos escritos de Benjamin Constant, cuja obra propõe uma diferenciação teórica entre a liberdade dos antigos e a liberdade dos modernos. A primeira liberdade em questão trata da política, onde a participação dos cidadãos é o meio pelo qual se garantem direitos e privilégios, ainda que em possível detrimento de suas direitos individuais. Quanto à segunda, a liberdade dos modernos, Constant

\footnotetext{
${ }^{13}$ MADISON, James. Federalist Paper n. 10. In: BOAZ, David. The Libertarian Reader. Simon \& Schuster, 2010. pp. 17 (tradução nossa)

${ }^{14}$ MILL, John Stuart. Sobre a liberdade. São Paulo: Edições 70, 2006. pp 34
} 
coloca-a como prática e ampliação dos direitos individuais, "o direito de não se submeter senão às leis" ${ }^{15}$, e de exercer sua individualidade conforme lhe convier.

Essa distinção exemplifica como era tratada a ideia de liberdade no período referenciado, evidenciando a distinção entre a atuação política do cidadão em contraponto ao exercício de suas liberdades e individualidades na esfera privada, ressaltando, por fim, o perigo oriundo da exclusão de uma das liberdades, política ou civil, cujo resultado seria a escravidão, sob diversas formas. Constant conclui, então, pela necessidade de combiná-las, de modo a possibilitar a realização do gênero humano por meio da elevação da dignidade moral dos cidadãos.

O século XX: Do totalitarismo à social democracia

De acordo com Ludwig von Mises, o programa político originado pelos filósofos do século XVIII e início do século XIX, qual seja, o liberalismo, nunca foi completamente implementado. ${ }^{16}$ Entretanto, posiciona que em determinados contextos históricos e políticos os princípios liberais foram, em certa escala, aplicados, e que esses pontuais adventos, tendo como ápice a revolução americana, mudaram a compreensão que se tinha de mundo, especialmente no que concerne à economia.

Contrario sensu, houve ainda o que se conhece atualmente por democracia liberal ou república democrática, segundo a qual o Estado não participa dos direitos dos cidadãos e da economia de modo geral, valendo-se de princípios como a laicidade e isonomia e, onde se aplica, da auto regulação, mostrando-se, desta forma, como uma continuação da perspectiva liberal anterior. (BOBBIO, 1997)

Nesse contexto, pode-se extrair que, em suma, o funcionamento do sistema britânico baseia-se no pensamento liberal de Locke e Montesquieu, posteriormente aperfeiçoado pelos norte-americanos. Ou seja, a própria ideia de democracia liberal, que surge a partir desses dois contextos anglo saxônicos, pode ser considerada uma aplicação concreta da ideologia liberal clássica, complementando a interpretação de Mises sobre a aplicação de tal.

\footnotetext{
${ }^{15}$ CONSTANT, Benjamin. Da liberdade dos antigos comparada à dos modernos. Revista Política n.2. 1985.

${ }^{16}$ MISES, Ludwig von. Liberalismo segundo a tradição clássica. 2.ed. São Paulo: Instituto Ludwig von Mises, 2010
} 
Em que pese esses episódios liberais pontuados por Mises, tais como as democracias liberais acima delineadas, já a partir da segunda metade do século XIX e, principalmente, o século $X X$ de modo geral, o que se viu, permeando todos os conflitos presentes à época, foi o crescimento do Estado que, sob diversos argumentos, ampliava sua atuação em diversas searas, como pode-se notar no surgimento de direitos sociais na Alemanha, no intuito de manutenção da paz social que, abalada pelos conflitos armados e crises econômicas, restava pontualmente desacreditada pelo povo.

Ato contínuo, percebe-se no período pós primeira guerra uma expansão das atribuições estatais frente à sociedade, gozando principalmente do apoio social, em razão da ideia de segurança que este representa e dos programas que fomentava, tal como o New Deal de Roosevelt em 1930, estudado e modificado por Keynes em 1936 para o veio a ser conhecido como Estado de Bem Estar Social.

Tal cenário de ampliação das prerrogativas estatais não era exclusividade dos Estados Unidos. A Europa, desde o fim da Primeira Guerra até o rompimento da Segunda, restava dividida entre os países que adotaram o socialismo, os que buscaram o fascismo como reação a ele, e os países que optaram pela social democracia, qual seja uma com maior atuação do governo no meio social, seja ele em forma de benefícios ou regulações. (HOBSBAWM, 1997)

Eric Hobsbawm argurmenta que o medo da revolução social, e do papel dos comunistas nela, era algo concreto no período entre guerras, mas que durante esse período, tido como os anos de enfraquecimento do liberalismo, os movimentos de esquerda não foram responsáveis pela queda de nenhum regime liberaldemocrático. ${ }^{17}$

A Constituição Alemã de 1919, conhecida também como Constituição de Weimar foi o primeiro texto constitucional que, contrariando a tese liberal da autonomia econômica, defendia que a intervenção do Estado na economia deveria buscar a transformação do sistema econômico (AVELÃS NUNES, 2011), integrando, desta forma, a esfera econômica e política, marcando a passagem da democracia liberal à social democracia.

Entretanto, este cenário de ampliação da atuação governamental no meio social predominante no período, como forma de aplacar tal revolução, bem como o

\footnotetext{
${ }^{17}$ HOBSBAWM, Eric. A Era dos Extremos. São Paulo: Editora Schwarcz LTDA., 1997 pp. 93
} 
lento progresso da política liberal, mostrou-se contraproducente do ponto de vista libertário, demonstrando ser terreno fértil para a disseminação das ideias marxistas, especialmente no que concerne à distribuição de riquezas e igualdade de resultados, que lograva de rápida satisfação. (HAYEK, 2010)

Variante do mesmo totalitarismo que o controle da atividade econômica tende a produzir $^{18}$, oriundos também do desgaste do modelo liberal no período entre guerras, o fascismo e o nazismo ascenderam em resposta às mesmas tendências que alavancaram o socialismo, valendo-se, inclusive, dos mesmos mecanismos para sua ascensão, em especial a promoção do coletivismo.

Diferem, contudo, tais movimentos, no que diz respeito à política econômica adotada, uma vez que os primeiros, resguardavam, em essência, os direitos de propriedade necessários à manutenção da economia capitalista, enquanto o segundo buscava não só uma sociedade eqüitativa, mas uma economia planificada e controlada para a consecução destes objetivos.

O fascismo, enquanto sistema de governo que cartelizou o setor privado e planejava centralmente a economia (ROCKWELL, 2014), reforçava a ideia já vista no New Deal de que o poder estatal era a única forma de alcançar a ordem social, por meio da justa distribuição de renda. Nesse contexto, a primeira esfera atingida pela regulação econômica do Estado foi a de direitos fundamentais, onde todas os indivíduos passam a ser supervisionados pelo aparato estatal, gerando com isso, assombroso crescimento do Estado policial.

O nazismo, em particular, em sua proposta anticomunista, preservava a ideia de propriedade privada e, ainda que valendo-se de mecanismos intervencionistas, buscava incentivar a política econômica necessária à expansão e prosperidade do sistema. Nesse particular, tem-se o que ficou conhecido como milagre econômico alemão, onde "ao mesmo tempo em que políticas do receituário keynesiano foram aplicadas a fim de contornar as falhas imputadas às políticas econômicas liberais de até então, a economia caminhava na direção de um grau maior de planificação centralizada."19

Com o fim da Segunda Guerra restou estabelecido o "Estado de Bem-Estar Social”, que, conforme coloca Vicente, visava a reestruturação e expansão dos

\footnotetext{
${ }^{18}$ HAYEK, Friedrich. O Caminho da Servidão. São Paulo: Instituto Ludwig von Mises: 2010 ${ }^{19} \mathrm{FEIJO}$, Ricardo Luis Chaves. Uma interpretação do Primeiro Milagre Econômico Alemão (19331944). Rev. Econ. Polit., São Paulo, v. 29, n. 2, p. 245-266, Junho 2009
} 
países capitalistas após as tensões das Guerras, ficando conhecido então como a era de ouro do capitalismo, ainda que "a expansão industrial, mesmo que com índices diferenciados, tanto acontecia nos países capitalistas como nos socialistas." (VICENTE, 2009)

Contudo, em meados da década de 70 eclodiu o que ficou conhecido como Crise Fiscal, que nada mais era que o colapso do modelo de Bem-Estar Social vigente, cujo funcionamento girava sob uma alta arrecadação tributária e maior ingerência do Estado por meio de benefícios sociais e redistribuição. Ato contínuo, o Estado de bem-estar social passou a ser visto como mau gestor econômico, ao mesmo tempo em que se defendiam a livre-iniciativa e o livre mercado, vistas como mais aptas a estimula a economia do que o Estado. ${ }^{20}$ Nesse contexto pontua Hobsbawn:

Encerrou-se um extenso período de governo centrista e moderadamente social-democrata [...]. Governos da direita ideológica, comprometidos com uma forma extrema de egoísmo comercial e laissez-faire, chegaram ao poder em vários países por volta de 1980. (Hobsbawm, 1995, p.245)

Nesse contexto, duas formas de organização política restaram das tensões do século $X X$, quais sejam o neoliberalismo e a social democracia. O primeiro figura como um retorno à ideais liberais após o fracasso do Estado de Bem-Estar Social, prezando, sobretudo, o livre mercado global. A social democracia foi mais amplamente aceita e melhor aplicada, especialmente em solos que haviam vivenciado o Estado de Bem-Estar Social e buscavam preservar alguns de seus benefícios.

Em que pese a utilização uniforme do termo, cumpre diferenciar a ideia de social democracia utilizada nos Estados Unidos para a definição estabelecida pela Internacional Socialista, sendo que para a primeira, na seara reformista, esta lhe servia como meio para manutenção da paz social, um modo de diminuir as tensões sociais inflamadas pelas revoluções sociais em curso na segunda metade do século. Para a Internacional Socialista, adepta do meio revisionista, a social democracia atua como uma forma ideal de democracia representativa, onde a igualdade e a justiça social sobrepõem-se às liberdades individuais para possibilitar uma transição pacífica ao socialismo. Um terceiro viés de tal ideologia veio representado pela aliança da social democracia com partidos de centro, substituindo em sua pauta a

\footnotetext{
${ }^{20}$ VICENTE, MM. História e comunicação na ordem internacional [online]. São Paulo: Editora UNESP; São Paulo: Cultura Acadêmica, 2009. p. 126
} 
justiça social por direitos humanos, resultando no que se tem hoje por Partidos Verdes. $^{21}$

Libertarianismo

O termo libertarianismo, até onde se tem notícia, foi primeiramente utilizado na segunda metade do século XX, quando, após as marcantes mutações políticas da época, a denominação de liberalismo clássico já não mais servia ao seu propósito original. Em suma, trata-se de um movimento que, em termos teóricos, se opõe às premissas liberais e suas simplificações e, em termos práticos, às políticas do welfare state e derivados. A título de esclarecimento etimológico, a utilização do termo libertarianismo, inaugurada por Leonard Read em 1950, buscava evidenciar a diferença entre o que à época estava sendo rotulado de liberalismo e o que de fato pretendia a filosofia em defesa da liberdade, seja ela civil, política ou econômica.

Desta feita, o que se tem atualmente por libertarianismo é "a visão de que cada pessoa tem o direito de viver da forma como escolher, contanto que respeite 0 mesmo direito dos outros. (...) Libertários defendem o direito individual de cada um à vida, liberdade e propriedade - direitos possuídos naturalmente, antes da criação do Estado."22

David Boaz, expoente da ideologia libertária na atualidade, dedica-se em alguns escritos à análise política das principais ideologias que nortearam o mundo durante o século $X X$ (entre as quais o fascismo, o comunismo, o socialismo e o Estado de bem-estar social) com vistas a definir, por contraste a elas, o que viria ser o libertarianismo, e explicar o porquê de estar ganhando força na atualidade. Segundo ele, a falha em comum entre as ideologias apontadas seria a tentativa de controle da economia, seja por centralização ou redistribuição, que se mostraria fadada ao fracasso por limitar a capacidade econômica de um país, a exemplo do lento crescimento econômico dos EUA e Europa na década de 70, inversamente proporcional ao aumento de impostos e regulamentações.

Desta feita, a social democracia que tem se consolidado ao longo do século $\mathrm{XX}$ até os dias atuais, tem encontrado oposição quanto às suas práticas, especialmente após a crise fiscal na década de 1970. Nesta ocasião, percebe-se

\footnotetext{
${ }^{21}$ LEFRANC, George. Socialismo Reformista. Lisboa: Circulo dos Leitores, 1974.

${ }^{22}$ BOAZ, David. Libertarianism: a primer. Washington, DC: Simon \& Schuster. 1998. pp. 6 (tradução nossa)
} 
que as pressões por uma economia essencialmente liberal incitavam "uma competição internacional cada vez maior e alimentava as demandas trabalhistas, canalizadas através dos sistemas institucionalizados de relações industriais e da representação política oferecida pelo welfare state keynesiano, fomentando novamente o debate sobre a liberdade e, paralelamente, sobre o libertarianismo ${ }^{23}$.

Murray Rothbard, icônico defensor do libertarianismo, em seu manifesto libertário já se questionava sobre o porquê do surgimento de um novo movimento libertário em prol da liberdade. Um dos principais pontos, segundo ele, foi a decadência interna do liberalismo, que não se limitou apenas à sua postura, mas também a princípios, "pois os liberais ficaram contentes em deixar o poder de travar guerras nas mãos do Estado, em deixar o poder da educação nas mãos do Estado, em deixar o poder sobre o dinheiro e os bancos, e sobre as estradas, nas mãos do Estado - em suma, em conceder ao Estado o domínio sobre todas as alavancas de poder cruciais à sociedade.". 24

Atualmente, notam-se alguns pontuais discursos libertários, cuja ascendência, embora lenta, conta com alguns apoiadores cuja relevância política ajudaram a disseminar a ideologia em questão. Ron Paul, membro do partido libertário dos Estados Unidos, prolífero escritor em defesa do libertarianismo, figura no cenário político americano como obstinado defensor das liberdades individuais e da limitação do Estado, veiculando, assim, ideias que haviam sido enfraquecidas desde a implementação da atual democracia americana.

Paul, no que concerne à política econômica mostra-se como proponente da Escola Austríaca de Economia, cujos patronos Ludwig von Mises, Carl Menger e Eugen von Böhm-Bawerk, preconizavam a organização espontânea do mercado baseada na complexidade das escolhas individuais, patrocinando, assim, o laissezfare para a economia. Nessa conjuntura, diversos teóricos do libertarianismo se mostram adeptos da escola austríaca no que concerne à sistemática econômica, uma vez que ambas buscam, nesse aspecto, o mesmo resultado, qual seja a prosperidade econômica baseada na liberdade individual.

Não obstante o viés político-econômico que invariavelmente traz a discussão do libertarianismo, essa filosofia abarca outras searas do pensamento, tais como os

\footnotetext{
${ }^{23}$ CLARKE, Simon. Crise do fordismo ou crise da social-democracia?. Lua Nova, São Paulo, n. 24, p. 117-150, Sept. 1991.

${ }^{24}$ ROTHBARD, Murray. O Manifesto Libertário. São Paulo: Instituto Ludwig von Mises, 2013. pp. 30
} 
princípios do direito natural que pavimentaram a discussão sobre a liberdade, representados na tríade de vida, liberdade e propriedade, inerentes à condição humana para nortear a vida social em determinado local.

Quanto ao exercício do direito à vida, haveria uma série de fatores que possibilitam seu exercício com maior ou menor grau de conforto, trazendo à tona discussão sobre a ideia de igualdade e seu exercício. Boaz busca distinguir três tipos de igualdade no exercício desse direito, quais sejam a igualdade perante a lei, a igualdade de resultados e a igualdade de oportunidades, sendo que somente 0 primeiro conceito seria aplicável em uma sociedade livre. Segundo ele, a possibilidade de igualdade de oportunidades e resultados é incompatível com a natureza limitada dos recursos disponíveis contrastados com os desejos humanos ilimitados, de modo que somente a igualdade perante a lei, que permite ao homem segurança para persecução de seus objetivos, seria viável e justa. ${ }^{25}$

Essa perspectiva quanto à liberdade de oportunidade, contudo, difere da proposta de Tocqueville, onde a igualdade perante a lei não difere da igualdade de oportunidades, mas origina-a. Em sua tese, Tocqueville identifica a igualdade com a democracia, e pondera, em análise a cenários específicos, como a tal igualdade pode coexistir com a ideia de liberdade, sem que se reprimam ou destruam mutuamente.

Contrapondo-se a esta ideia, tem-se a concepção adotada pelo socialismo, fundamentada nas teses desenvolvidas por Karl Marx, onde somente seria possível e existência da liberdade quando em um contexto de igualdade real, ${ }^{26}$ o que coaduna com a segunda concepção apontada por Boaz, a igualdade de resultados.

Nada obstante, segundo a perspectiva libertária, a priorização da igualdade material como objetivo absoluto é incompatível com a liberdade e com a sociedade democrática, uma vez que buscando assistir os menos favorecidos, termina por punir, ainda que indiretamente, a individualidade e autonomia dos demais. Como concluiu Milton Friedman, "Uma sociedade que coloca a igualdade à frente da liberdade terminará sem as duas. O uso da força para alcançar a igualdade irá

\footnotetext{
${ }^{25} \mathrm{Em}$ contraposição, tem-se a ideia americana de igualdade, onde a tanto a lei quanto as oportunidades devem servir de forma neutra aos cidadãos, de modo que todos, independentemente de suas particularidades, possam atuar e prosperar na sociedade, ideia essa consolidada na Declaração dos Direitos do Homem e do Cidadão, na Declaração de Independência dos EUA, na Constituição Federal Brasileira e em diversos outros dispositivos legais da democracia moderna.

${ }^{26}$ PEREIRA, Potyara A. P.. O sentido de igualdade e bem-estar em Marx. Rev. katálysis,

Florianópolis, v. 16, n. 1, p. 37-46, Junho 2013.
} 
destruir a liberdade, e a força, introduzida com bons propósitos, irá terminar nas mãos de pessoas que irão utilizá-la para promover seus próprios interesses". ${ }^{27}$

Outrossim, o conceito de liberdade proposta pelo libertarianismo, em sua essência, gira em torno da ideia de autonomia do indivíduo, onde este, em usufruto da igualdade perante a lei e isonomia do mercado, pode construir sua vida conforme Ihe convier, desde que não ofenda o mesmo direito de seus concidadãos.

É o que se extrai, em essência, das teses libertárias de Boaz, em que este pontua que, independentemente do conceito de liberdade empregado, é ponto pacífico que os indivíduos, enquanto seres dotados de discernimento são, não somente aptos mas detentores exclusivos do direito de se autodeterminar e tomar decisões sobre sua vida.

O direito à propriedade, por sua vez, necessita de maior cuidado em seu discurso, uma vez que a incompatibilidade de interpretações se mostra contraproducente à sua conceituação. De certa forma, todos os direitos nomeados podem ser considerados vertentes do direito de propriedade, isto porque esse direito não diz respeito somente à posse de bens materiais, mas também à propriedade sobre a própria força de trabalho, sua mente, e tudo que se originar da atividade empregada, como visto já em Locke. (BOAZ, 1997)

Partindo do pressuposto da propriedade como alicerce da sociedade livre, pode-se balizar a gama de direitos naturais pelo axioma da não-agressão, onde compreende-se que ninguém tem o direito de iniciar uma agressão contra outro e sua propriedade. Rothbard, em seu manifesto, conceitua:

"O credo libertário está baseado num axioma central: o de que nenhum homem ou grupo de homens pode cometer uma agressão contra a pessoa ou a propriedade de qualquer outro. Ele pode ser chamado de "axioma da não-agressão". "Agressão" é definida como o uso ou ameaça de violência física contra a pessoa ou propriedade de qualquer outro indivíduo. Agressão, portanto, é um sinônimo de invasão."28

Este princípio, cuja gênese data de tão longe quanto a própria ideia de liberdade lockeana, encontra respaldo em diversos pensadores libertários da atualidade, tal como Ayn Rand, que analisa o princípio da não-agressão como uma liberdade negativa, posto que seu enunciado apenas nega uma ação. Não obstante esse pensamento, Rand coloca seu oposto moral positivo, onde cada homem possui liberdade para agir sob seu próprio julgamento, para seus próprios objetivos, por sua

\footnotetext{
${ }^{27}$ Extraído do episódio Created Equal, da série de televisão Free to Choose. 1990, Volume 5.

${ }^{28}$ ROTHBARD, Murray. O Manifesto Libertário. São Paulo: Instituto Ludwig von Mises, 2013. pp 37
} 
escolha voluntária. Essencialmente, "significa que a maioria das decisões que tomamos diariamente envolve escolhas que são amplamente limitadas pela obrigação de respeitar os direitos dos outros". 29

Nesse sentido, pontua Rothbard, está a conceituação de liberdade pelo libertário, onde a liberdade é "uma condição na qual os direitos de propriedade de uma pessoa sobre seu próprio corpo e sua propriedade material legítima não são invadidos, e não sofrem qualquer agressão." (ROTHBARD, 2013) Nota-se neste conceito a conectividade entre liberdade e propriedade. Contraposto a isso está o seu conceito de escravidão, em que o direito de autopropriedade mostra-se constantemente violado.

Outrossim, o indivíduo libertário, é essencialmente um individualista, longe, porém, de ser um igualitário. A única igualdade possível em sua ideologia é "o direito igual de todo homem à propriedade de sua própria pessoa, da propriedade dos recursos ainda não usados de que ele "primeiro se apropriou", e da propriedade de outros que ele tenha adquirido através de doação ou troca voluntária." 30

Fundamentos da economia livre

Se até aqui, buscamos uma separação simbólica entre a filosofia política e a economia, agora adentramos em um território essencialmente econômico, ponto fundamental para, ao fim, aplicar a teoria desenvolvida ao contexto brasileiro. Afinal, essa distinção explícita entre política e economia, serve somente aos fins de organização material, uma vez que para persecução dos ideais libertários, ambas atuariam em uníssono na promoção de uma sociedade livre. (FRIEDMAN, 2014).

A grande questão da economia, independentemente do contexto político, é a mediação entre os recursos limitados (do mercado, no caso), e as necessidades ilimitadas das pessoas. Para essa função, o Estado pode atuar em duas frentes opostas, seja por meio da economia de mercado (capitalismo), seja por meio da economia planificada (socialismo). ${ }^{31}$

A economia de mercado fundamenta-se na liberdade dos agentes econômicos de atuarem no meio com a mínima intervenção do Estado, seja ela direta, quando este entra na economia como competidor, seja a intervenção indireta,

\footnotetext{
${ }^{29}$ BOAZ, David. Libertarian mind. Washington, DC: Simon \& Schuster. 1998. pp. 98 (tradução nossa) ${ }^{30}$ ROTHBARD, Murray. O Manifesto Libertário. São Paulo: Instituto Ludwig von Mises, 2013. pp.. 58 ${ }^{31}$ MANKIW, N Gregory. Introdução à Economia. São Paulo: Cengage Learning: 2014
} 
por meio de regulamentações e controles. Nesse contexto, os indivíduos encontramse livres para se inserirem no mercado conforme desejarem, sendo remunerados pelo valor que gerarem com seus serviços e participando, ainda que inconscientemente, numa rede de harmonia de interesses ${ }^{32}$, possibilitando não só que cada um atue no ramo que desejar, mas que adquira o produto e serviço que Ihe convier, assegurado pela concorrência vigente.

Histórico marco no estudo da economia moderna, Adam Smith estruturou sua tese na premissa de que o interesse próprio, primordialmente, promovia 0 crescimento econômico. De sua teoria, extrai-se a ideia de mão invisível do mercado, onde a livre competição determinaria o preço dos produtos de acordo com a demanda, bem como promoveria um aprimoramento de tais produtos como forma de angariar e manter a clientela. Nesse contexto, o cliente escolheria o produto que Ihe conviesse, de acordo com as suas exigências, e o mercado, ao adaptar-se a isto, seria aprimorado.

Essa ideia foi posteriormente aperfeiçoada por Hayek sob o título de ordem espontânea, que a conceitua com "uma condição em que múltiplos elementos de vários tipos se encontram de tal maneira relacionados entre si que, a partir de nosso contato com uma parte espacial ou temporal do todo, podemos aprender a formar expectativas corretas com relação ao restante ou, pelo menos, expectativas que tenham probabilidade de se revelar corretas" ${ }^{\prime 33}$ Para ele, essa ordem natural, estabelecida no livre mercado, é o antídoto ao racionalismo construtivista, utilizado no processo fascista e socialista, cujo cerne traz consigo fundamentos totalitários. ${ }^{34}$

No mesmo sentido, argumenta Rothbard, a economia de livre mercado é, comprovadamente, a forma mais produtiva de economia conhecida pelo homem, responsável pela economia tal como a conhecemos hoje, sobre a qual a civilização ocidental foi construída Desta forma tem-se o que Adam Smith chamou de "o sistema da liberdade natural", como a economia de mercado atualmente aplicada, onde "por mais complexa que seu sistema possa parecer na superfície, nada mais é que uma vasta rede de trocas voluntárias e de comum acordo estabelecidas entre duas pessoas"35

\footnotetext{
${ }^{32}$ MISES, Ludwig von. As seis lições. São Paulo: Instituto Ludwig von Mises: 2009. pp 32

${ }^{33}$ HAYEK, Friedrich A. Direito, Legislação e Liberdade, vol. 1. São Paulo: Visão. 1985. pp. 36

${ }^{34}$ HAYEK, Friedrich A. O caminho da servidão. São Paulo: Instituto Ludwig von Mises: 2010

${ }^{35}$ ROTHBARD, Murray. O Manifesto Libertário. São Paulo: Instituto Ludwig von Mises, 2013. pp 56
} 
Doutra feita, a economia planificada analisa o comércio sob outra ótica, pontuando não a harmonia, mas o conflito de interesses no meio econômico. Tal modelo de organização, também conhecido como economia centralizada ou centralmente planejada, baseia-se na premissa da eficiência por meio do planejamento único, ou seja, o Estado centraliza os meios de produção e controla a dinâmica da atividade econômica a partir daí.

Esse mecanismo de organização econômica foi primeiramente utilizado na URSS, em 1928, quando Stalin implementou o que ficou conhecido como planos quinquenais, cuja ênfase voltava-se ao estabelecimento de prioridades para os setores industrial e agrícola do país num período de cinco anos. Mises critica esse modelo de economia pontuando a impossibilidade de cálculo de preços e, consequentemente, de uma meta de produção, uma vez que a demanda, fator indispensável a essas previsões, é negligenciada em seu caráter subjetivo no processo de organização. (MISES, 2009)

A liberdade econômica prometida pela economia planificada significa, na essência, a transferência da responsabilidade de decisão para outros, geralmente o governo. Pontua Hayek que, por dependermos em tão grande escala dos bens proporcionados pela sociedade, o planejamento econômico importaria o controle da quase totalidade da vida civil. Nesse contexto, "não existiria praticamente nenhum aspecto desta - desde as necessidades primárias até as relações de família e de amizade, da natureza do nosso trabalho até o uso que fazemos de lazer - sobre o qual o planejador não exercesse seu "controle consciente",36

De forma diversa se posiciona a Seção brasileira do Comitê por uma Internacional dos Trabalhadores que, partindo da obra Red Planty, de Francis Spufford, discorre dobre as conquistas e o potencial da economia planificada. Argumentam que a planificação da economia na URSS produziu mais cientistas, engenheiros e técnicos do que o resto do mundo junto, além da distribuição da renda de acordo com critérios diferenciados. Sobre isso Spufford pontua: "Os salários dos trabalhadores foram aumentados, e os salários da elite foram congelados, criando uma divisão de renda muito mais igualitária”37.

Um meio termo entre a economia de mercado pautada na liberdade e a economia planificada é o que se conhece por economia mista, ou

\footnotetext{
${ }^{36}$ HAYEK, Friedrich. O Caminho da Servidão. São Paulo: Instituto Ludwig von Mises: 2010. pp.104

${ }^{37} \mathrm{http}: / /$ www.Isr-cit.org/cultura/40-cultura/684-a-abundancia-vermelha-e-possivel-a-economiaplanificada-e-a-luta-pelo-socialismo
} 
como nomeada por Mises, ordem obstruída de mercado. Trata-se de uma economia baseada no intervencionismo estatal, valendo-se do uso limitado dos poderes discricionários do governo (intervenção) para lidar com problemas identificados com a propriedade privada dos meios de produção e o processo de mercado desregulado. A intervenção, de acordo com Ludwig Von Mises"é um decreto, estabelecido direta ou indiretamente, pela autoridade responsável pelo aparato administrativo de coerção e compulsão da sociedade que força os empreendedores e capitalistas a usarem alguns dos seus fatores de produção de uma maneira diferente que eles usariam caso estivessem apenas obedecendo aos ditames do mercado." ${ }^{38}$

John Maynard Keynes, um dos principais defensores do intervencionismo trata em sua obra, Teoria geral do emprego, do juro e da moeda, do que hoje ficou conhecido por keynesianismo. Consiste em uma orgazição econômica baseada na ingerência do Estado, objetivando manter o crescimento da demanda igual ao aumento da capacidade produtiva da economia, em proporções suficiente para garantir o pleno emprego sem gerar um crescimento de renda que resultasse em inflação. Ademais, em casos de crise econômica, o Estado deveria intervir positivamente na economia, ou seja, injetando dinheiro por meio de gastos públicos para aumentar a demanda e reaquecer a economia. Herdeiros do keinesianismo argumentam que

"Keynes assinalou a importância da demanda agregada, e legitimou
o recurso a déficits fiscais em momentos de recessão. No entanto,
jamais defendeu déficits públicos crônicos. Seu pressuposto foi
sempre o de que uma economia nacional equilibrada, do ponto de
vista fiscal, poderia, por um breve período, sair do equilíbrio para
restabelecer o nível de emprego."

Oposto a esta política surgiu o monetarismo de Mises, que criticou o intervencionismo, em suma, pela sua inconsistência lógica, não se debruçando sobre a desejabilidade dos seus, argumentando que 0 intervencionismo, diferentemente do socialismo ou capitalismo, é indefensável como doutrina e é inerentemente instável como um sistema por ser contra as forças fundamentais da economia, qual seja a principal a persecução do lucro. (IKEDA, 1994)

Diversas escolas econômicas, direcionadas à análise das teorias econômicas mencionadas, surgiram ao longo dos séculos dezenove e vinte com a função

\footnotetext{
${ }^{38}$ MISES, Ludwig von. Ação Humana: Um Tratado de Economia. São Paulo: Instituto Ludwig von Mises Brasil, 2010, pp.718

${ }^{39}$ BRESSER-PEREIRA, Luiz Carlos. O Novo Desenvolvimentismo e a Ortodoxia

Convencional. São Paulo: São Paulo em Perspectiva, v. 20, n. 3, p. 5-24, jul./set. 2006
} 
precípua de legitimar ou criticar determinada vertente de pensamento econômico. A escola austríaca de economia, também conhecida como escola de Viena, que tem por fundadores iniciais Carl Menger, Eugen von Böhm-Bawerk e Ludwig von Mises, baseia-se no individualismo para determinação de teorias econômicas, defendendo a essência do livre mercado, onde as escolhas subjetivas individuais atuam livremente e a organização econômica se dá por meio de contratos voluntários entre os agentes econômicos. 


\section{METODOLOGIA}

O intuito do presente trabalho passa pela averiguação das hipóteses postas em seu projeto, quais sejam: o contexto social e econômico brasileiro nos últimos vinte anos aparece como ambiente propício ao surgimento de uma resposta libertária na sociedade; e que os partidos e movimentos políticos, assim como algumas figuras específicas, surgiram e galgaram relevância política em tempos recentes baseados em premissas libertárias, ainda que modificadas para sua aplicação na conjuntura brasileira. Os objetivos precípuos vinculados a essas hipóteses passaram pela delimitação teórica dos conceitos de ideologia e libertarianismo.

Dessa feita, a pesquisa adotou, inicialmente, um caráter qualitativo, onde estudou-se as fontes primárias que embasam o libertarianismo, assim como identificou e conceituou o que se tem atualmente por ideologia. Para tanto, a análise de alguns autores chave foi essencial para a apreensão de conceitos relativamente homogêneos e bem definidos.

Nesse contexto, trabalhando ideologia, autores como Boudon e Eagleton foram de suma importância para nortear esse percurso, uma vez que ambos tratam o conceito em suas obras sob diversas óticas, possibilitando o estudo e síntese da ideia a ser implementada aqui.

Posto isto, para compreender as origens do libertarianismo, buscou-se apreender os fundamentos teóricos da liberdade para uma concepção mais ou menos clara de sua significação. Sobre o assunto, John Locke foi o marco inicial na revisão bibliográfica, de cuja obra se extraem premissas como proteção da vida, liberdade e propriedade dos indivíduos.

Ato contínuo, passou-se a análise de outros teóricos que, sobre o mesmo tema, incrementaram ou modificaram os princípios iniciais, como Montesquieu e sua tese sobre a separação dos poderes e Mill com o utilitarismo.

Tais teóricos e teorias foram utilizadas como balizadores desta pesquisa, em especial quando necessária a análise das ideologias que pontuaram o século $X X$, objeto de uma seção específica, onde foram averiguados os contextos de conflito e prosperidade que se alternaram ao longo do século, modificado profundamente a compreensão e implementação de ideologias. 
Em seguida, procedeu-se uma análise superficial de alguns princípios econômicos por meio de bibliografia especifica, agora um tanto fora das primeiras utilizadas, posto possuir um caráter mais técnico, contudo essenciais à aplicação política de determinadas premissas, sintetizando, ao fim, os conceitos trazidos por Smith sobre a economia livre, bem como dos ideais defendidos por Marx quanto ao seu controle, e permitir uma análise mais específica e direcionada do contexto brasileiro a partir da implementação do Plano Real em um cenário de evidente pluralidade ideológica-econômica.

Feitas as definições teóricas referentes à ideologia e libertarianismo, por fim, seguiu-se à análise da conjuntura brasileira, ponto fulcral dessa pesquisa, sendo necessário, portanto, a implementação da bibliografia elencada, dado as especificidades da formação político-ideológica. Nesse sentido integraram a análise autores como Max Weber e sua concepção de patrimonialismo, segundo a qual o Estado não distingue limites entre o público-privado.

Outrossim, não obstante a ênfase econômica na análise das ideologias apresentadas, buscou-se ainda apreender a sociedade a partir do pensamento dos sujeitos e seu vínculo recíproco com a realidade social, na esteira da perspectiva sustentada por Weber. Para tanto, buscou-se um diálogo entre as teorias vistas até então e a conjuntura política propriamente dita, valendo-se, para tanto, de páginas independentes de discurso político e notícias que identificaram alguns períodos que exemplificaram a implementação ou modificação das teorias descritas.

Em suma, essa pesquisa buscou identificar e analisar fatores específicos, passíveis de gerar uma resposta de cunho libertário no cenário brasileiro atual, assim como investigar o quanto dessa ideologia integra os partidos e movimentos que se propõem a defendê-la.

Ademais, inicialmente, tencionava-se realizar uma pesquisa calcada em entrevistas com ícones políticos e figuras chaves dos partidos supracitados que defendem ideais libertários, como o Partido NOVO e o Movimento Brasil Livre, estruturadas em torno dos temas teóricos em pauta, com o propósito de analisar o conceito brasileiro atual de libertarianismo e o que essa nova geração de partidos defende em comum com os pressupostos clássicos dessa ideologia.

Contudo, tal objetivo não prosperou, uma vez que a pesquisa teórica demandou mais do que o inicialmente previsto, desembocando em novos temas que 
precisavam ser analisados e contextualizados, modificando, ao fim, os rumos previstos no projeto original.

Desta feita, toda a pesquisa foi empreendida no escopo qualitativo, voltado para interpretação e contextualização das bibliografias selecionadas, buscando com isso um diálogo entre as teorias anteriormente elencadas e os contextos nos quais foram aplicadas para, por fim, serem analisadas sob a ótica da atual conjuntura brasileira, visando à apuração das hipóteses inicialmente propostas. 


\section{RESULTADOS}

Tendo em vista os objetivos propostos, no que diz respeito à operacionalização do conceito de ideologia, buscamos, no presente trabalho, preservar a ideia central do conceito formulado por de Tracy, onde temos a ideologia como algo positivo e passível de embasamento cientifico e, paralelamente, mesclar as teorias de Althusser e Gramsci, compreendendo o conjunto formador mantenedor das ideologias no âmbito dos Aparelhos Ideológicos de Estado e da hegemonia, bem como a concepção de "representação imaginária dos indivíduos com as suas condições reais de existência". ${ }^{40}$ Desse modo, compreende-se a ideologia como algo essencialmente positivo e necessário à vida social, em especial no campo político, levando em consideração, entretanto, a forma como se dá a construção de tais ideologias e a compreensão delas no cotidiano, partindo do pressuposto de que "a ideologia surge não apesar do homem ser racional, mas porque ele é racional", ou seja, como uma representação coerente de determinado contexto. ${ }^{41}$

Passando a uma interpretação concreta das ideologias que fundamentam o libertarianismo, pode-se vislumbrar o que persiste do conceito de liberalismo clássico, que permanece, essencialmente, adstrito aos direitos inicialmente pontuados por Locke, quais sejam vida, liberdade e propriedade, a despeito das modificações históricas e contextuais.

Em vista disso, sob o esteio do conceito de ideologia posto, a corrente liberal mostra-se como uma resposta racional de determinado grupo ao contexto social em que se insere, tal como o socialismo, o comunismo e a social democracia. Desta forma, o liberalismo atua como um movimento ideológico que, com base nos valores defendidos, propõe uma interpretação específica do meio sócio-político e soluções que coadunam com seus princípios

Vê-se tal ideia em alguns icônicos marcos liberais como a Revolução Gloriosa ocorrida na Inglaterra em 1688 e a implementação da Bill of Rights, cenário em que se contempla, de forma patente, os princípios trabalhados por John Locke em prol das liberdades individuais frente ao absolutismo. Demonstra-se então como seu a defesa da liberdade enquanto expressão política e jurídica no contexto das monarquias e regimes absolutistas, onde os liberais buscavam a proteção da

\footnotetext{
${ }^{40}$ ALTHUSSER, Louis. A parelhos ideológicos de Estado. 10. Ed. Rio de Janeiro: Editora Graal. 2007. pp. 94

${ }^{41}$ BOUDON, Raymond. A Ideologia. São Paulo: Editora Atica. 1998. pp. 19
} 
liberdade dos indivíduos contra essa tirania, refletindo "as aspirações da classe média em ascensão, cujos interesses entravam em conflito com 0 poder estabelecido dos monarcas absolutistas e da aristocracia rural" (HEYWOOD, 2010, p. 38). No lugar do absolutismo vigente baseado no "direito divino" dos reis, os liberais visavam a um governo constitucional onde pudessem preservar e exercer as liberdades fundamentais pontuadas anteriormente, influenciando, dessa forma, movimentos revolucionários como a Revolução Inglesa, Americana e Francesa.

Contudo, a defesa da liberdade não implica na crença de que os indivíduos devem gozar de uma liberdade absoluta e sem regras, de modo que, do ponto de vista político, o liberalismo clássico acredita na necessidade do Estado, cuja função precípua é proteger as liberdades individuais, impondo certas restrições aos indivíduos ao mesmo tempo em que lhes assegure o usufruto da liberdade através de leis: "A liberdade, portanto, só pode existir 'sob a lei', conforme afirmou John Locke, 'onde não há lei, não há liberdade'” (HEYWOOD, 2010, p. 49)

Por fim, constata-se destes exemplos a evolução da ideia liberal, não apenas no que diz respeito à sua significação, mas também como as formas de aplicá-la em determinados contextos políticos, de modo que se mostre como uma resposta eficiente aos problemas e cenários que se apresentam em determinado meio social.

Como contraponto à perspectiva liberal, findadas as guerras que pontuaram o século XX, adotou-se no Ocidente, majoritariamente, a ideologia social-democrata de tipo americano, onde as intervenções estatais eram defendidas como forma de promoção e manutenção do Estado de Bem-Estar Social dentro do sistema capitalista, utilizando-se, para tanto, do tripé mantido até hoje nos países democráticos, qual seja, regulação econômica, justa redistribuição de renda e democracia representativa.

Observa-se aqui a predominância de uma ideologia direcionada para a promoção do bem estar social, sobrepondo aqui o interesse social à autonomia da vontade individual. Isso ocorreu, contrariamente às disposições liberais, em resposta aos conflitos que marcaram o século XX pela supressão não só das liberdades, mas especialmente dos frutos econômicos e sociais que ela gerara em seu apogeu. Com o intenso baque econômico posterior às guerras, o liberalismo começou a admitir a tendência intervencionista do Estado, para solucionar os problemas sociais, demonstrando, então, a concepção de ideologia como uma reação racional do indivíduo ao contexto em que ele se insere. 
Por sua vez, frente a tal contexto, temos o libertarianismo não só como uma filosofia voltada à organização econômica e limitação do Estado, tal como fazem parecer a maioria dos debates políticos em que é trazido à tona, mas também, e principalmente, uma doutrina que advoga em prol da autonomia do indivíduo e de sua liberdade, seja ela civil, política ou econômica.

Cumpre ressaltar, contudo, que o libertarianismo, ao contrário do anarquismo, não afirma buscar a extinção absoluta do governo civil, posto reconhecer a necessidade deste para a manutenção da organização político-social. Sobre isso, encontra-se respaldo na própria fundação do Estado liberal clássico, quando Madison argumenta sobre "o que é o próprio governo, senão a maior das críticas à natureza humana? Se os homens fossem anjos, não seria necessário governo algum. Se os homens fossem governados por anjos, o governo não precisaria de controles externos nem internos"42

Outrossim, aplica-se novamente o conceito de ideologia que norteia esta pesquisa, qual seja de que a ideologia surge como uma resposta racional de um indivíduo ou grupo a uma determinada conjuntura social. Desta forma, o surgimento do libertarianismo pode ser visto aqui como reflexo a um cenário sócio-político de crescimento do controle estatal, onde seus conceitos e valores mostram-se cabíveis como uma possível solução às desavenças, ainda que opostas às premissas e políticas do welfare state e derivados, por retirar do "Estado o domínio sobre as alavancas de poder da sociedade."43

Nesse contexto, percebem-se as flutuações ideológicas que permearam a economia ao longo da história, inclinando-se sobre esta ou aquela vertente a depender do contexto fático em que se inseria. Dos conceitos trazidos por Smith sobre a economia livre, bem como dos ideais defendidos por Marx quanto ao seu controle, ainda há resquícios na economia contemporânea, o que, levando-se em conta tanto o cenário político quanto a formação cultural onde analisada, demonstra uma pluralidade ideológica-econômica a pender para um dos polos.

Partindo das perspectivas teóricas e ideológicas discutidas, Antônio Paim argumenta que "os níveis de estatização da economia brasileira aproximam-se

\footnotetext{
${ }^{42}$ MADISON, James. O Federalista n. 51: A Estrutura do Governo deve Fornecer os Freios e Contrapesos (Checks and balances) Adequados entre os Diversos Departamentos. https://perguntasaopo.files.wordpress.com/2010/06/fed51.pdf ${ }^{43}$ ROTHBARD, Murray. O Manifesto Libertário. São Paulo: Instituto Ludwig von Mises, 2013.
} 
bastante daqueles alcançados pelos países socialistas" ${ }^{44}$, posto o domínio estatal na esfera econômica ser quase absoluto, sendo um dos principais motivos o patrimonialismo presente no Estado brasileiro.

$\mathrm{Na}$ esteira de tal interpretação, Gustavo H. B. Franco, ex-presidente do Banco Central do Brasil, em seu artigo intitulado Precisamos falar sobre o capitalismo, afirma que no Brasil "pouca gente sabe definir o que é, mas muitos odeiam o capitalismo"45, questionando ao longo do texto o porquê de tal fenômeno. Duas possíveis causas para tal recusa ao sistema econômico vigente foram pontuadas, quais sejam "a apatia, muito provavelmente incentivada por valores nossos, mal cultivados", e o sucesso do capitalismo como causa da desigualdade.

Quanto ao primeiro, aduz que os sistemas de hierarquia e privilégios, já há muito consolidados no Brasil, são muito mais naturais e preferíveis à igualdade perante a lei e à impessoalidade. Sobre o segundo, enfoca o "capitalismo meio patrimonialista" vigente no Brasil, tido como um jogo onde as conexões com o governo, reserva de mercado e o jeitinho brasileiro ditam os rumos da economia, podendo ser visto como um dos motivos da crise brasileira em 1980. (FRANCO, 2015)

Ressalta-se aqui que tal cenário deve-se também ao patrimonialismo arraigado na cultura brasileira, onde o Estado e a sociedade se relacionam de modo a reproduzir os privilégios da burocracia estatal que gere o Estado, isento de regras impessoais ou racionais. (FAORO, 2000) Nessa linha, prossegue Faoro, tem-se o Estado Patrimonialista brasileiro, que, ao contrário de diversos países com sistemas liberais de governo, adota um modelo de organização política norteado pela dominação do público sobre o privado. ${ }^{46}$

Partindo disso, Caio Prado Júnior pontua o capitalismo brasileiro como uma forma de capitalismo político, com características específicas, "onde as empresas capitalistas são dependentes do setor público, em contraste com um capitalismo destacado do Estado, o que ocorre na situação clássica. O autor ressalta, com esta

\footnotetext{
${ }^{44}$ PAIM, Antônio. Agenda teórica dos liberais brasileiros. São Paulo: Massao Ohno Editor, 1997. pp. 40

${ }_{45}$ FRANCO, Gustavo H. B. Precisamos falar sobre o capitalismo. Quem move o mundo, 2016.

${ }^{46}$ FAORO, Raymundo. Os Donos do Poder - Formação do Patronato Político Brasileiro. São

Paulo, Globo. 2000.
} 
observação, que no patrimonialismo o poder público comanda o aparato burocrático, as forças militares e a economia." 47

Nesse contexto, mostra-se importante apontar a relação necessária que uma ideologia desenvolve com a conjuntura à qual se busca aplicar. Conforme discutido nas seções anteriores, uma ideologia responde, mediante construção racional, a constrangimentos contextuais dos mais diversos - no caso do liberalismo clássico, ao Estado absolutista, no caso do libertarianismo a concepções totalitárias e, mais adiante, social-democratas de organização política. Segundo os autores citados acima, a principal característica do contexto brasileiro à qual qualquer ideologia tem de se adequar e responder, seria o patrimonialismo. Partindo das definições de Max Weber $^{48}$, é possível identificar suas origens ainda na organização colonial portuguesa, ibérica. Segundo José Murilo de Carvalho, que taxa a relação existente entre o Estao e cidadãos no Brasil de "estadania", "[...] o Estado é sempre visto como todo-poderoso, na pior hipótese como repressor e cobrador de impostos; na melhor, como um distribuidor paternalista de empregos e favores." (CARVALHO, 2001, p. 221) Desse modo, ao abordarmos a penetração da ideologia libertária na realidade brasileira, é importante ter em mente as relações de estadania vigentes em nosso meio.

$\mathrm{Na}$ sequência, cumpre aqui esclarecer alguns aspectos do desenvolvimento econômico nacional nos últimos anos, de modo a viabilizar uma análise mais concreta da implementação e apreensão de determinadas ideologias políticas no país.

No Brasil, o início da década de 1970 ficou conhecida como milagre econômico. Nesse cenário, o governo Médici preocupou-se tanto com a aceleração do desenvolvimento econômico quanto com a meta de superação do subdesenvolvimento, possibilitando a manutenção da economia que crescia em velocidade compatível com as ambições alimentadas pelo regime. (MACARINI, 2005). Para Paim, caberia basicamente aos governos militares do período 1964-1984 introduzir uma organização econômica e urbana que colocasse o Brasil entre as maiores economias do mundo. (PAIM, 2000) O período 1968-1973 ficou conhecido

\footnotetext{
${ }^{47}$ AGUIAR, Neuma. Patriarcado, sociedade e patrimonialismo. Soc. estado., Brasília , v. 15, n. 2, p. 303-330, Dec. 2000 .

${ }^{48}$ Trata-se de uma forma de administração de cunho tradicional, organizada em torno de um senhor que se mostra o ponto fulcral e irresistível de toda a organização política e social. "Sendo o quadro administrativo totalmente dependente dele, não existe nenhuma garantia contra o seu arbítrio [...]" (WEBER, 2003, p. 132)
} 
como "milagre" econômico brasileiro, tendo em vista as enormes taxas de crescimento do Produto Interno Bruto (PIB) combinada a uma inflação declinante e relativamente baixa para os padrões brasileiros e superávits no balanço de pagamentos. (HAUSMANN, 2005)

Por outro lado, após 1973, com a eclosão da crise econômica deflagrada pelo mercado petrolífero, os impactos do controle pelo regime também mostraram seus efeitos no cenário brasileiro, a despeito do bom momento econômico. Segundo os jornais da época, nos anos de 1970 o Brasil importava 70\% do petróleo que consumia, tendo o preço do barril subido mais de 40\% em 1973.

"Gasolina não era vendida nos finais de semana e ficava proibido andar a mais de 80 quilômetros por hora nas estradas. As longas filas que se formavam nos postos de gasolina nas vésperas dos aumentos ainda está gravado na memória dos brasileiros que viveram o período, assim como o programa Proálcool e os investimentos feitos nas Usinas Nucleares de Angra dos Reis, soluções propagandeadas pelo governo militar para driblar a dependência do Brasil no setor energético". 49

Nesse cenário, o que se viu até 1985 foi um extenso período de predominância do autoritarismo, onde alguns liberais aliaram-se com os militares sob inspiração positivista, considerado a derrocada do liberalismo brasileiro, consolidando-se a ideia de que o liberalismo clássico não era capaz de lidar com a questão social. (CONSTANTINO, 2012)

Contudo, após a queda do regime, a despeito da estagnação econômica que assolava o país, o que ficou conhecido como a década perdida no Brasil mostrou-se um terreno fértil à difusão da ideia de liberdade. Recém saído de uma era de restrição de direitos, a persecução de uma maior autonomia individual começava a ganhar força no contexto político brasileiro, momento em que se firmaram inúmeras entidades e partidos populares - fruto das busca pela pluralidade e liberdade políticas -, rumo à promulgação da Constituição de 1988.

Entre 1990 e 1992 a economia esteve em recessão e a escalada inflacionária prosseguia. O início do governo Itamar ocorreu, de fato, na reforma ministerial de maio de 1993, quando FHC, deslocado do cargo de chanceler para o comando da Fazenda, propôs-se a combater a inflação com políticas liberalizantes (BACHA, 1998).

Nesse contexto, como marco material da presente pesquisa, cumpre analisar o impacto da implementação do Plano Real na modificação da postura ideológica

\footnotetext{
${ }^{49}$ http://acervo.estadao.com.br/noticias/acervo, alta-do-petroleo-fez-pais-viver-crise-nos-ano $1970,10618,0 . \mathrm{htm}$
} 
brasileira. Entretanto, deve-se ressaltar que não se trata do único gatilho da mudança apontada, posto a Reforma da Administração Pública ser considerada por muitos teóricos um marco liberal na organização estatal pós crise (BRESSERPEREIRA, 1996).

Criado durante a gestão do ex-presidente Itamar Franco, pelo então Ministro da Fazenda Fernando Henrique Cardoso, o Real tornou-se a moeda brasileira no dia $1^{\circ}$ de julho 1994. O Plano Real, por sua vez, foi o programa de estabilização econômica que visava ao fim da inflação elevada no Brasil, que perdurava havia trinta anos, pontuada por medidas econômicas inconsistentes, como congelamento de preços.

Quando implementado, o Plano proporcionou o controle da inflação através de mecanismos que permitiram uma ampla abertura ao comércio exterior, da mesma forma que aumentou a integração de nosso sistema financeiro aos mercados internacionais. O grande diferencial desse programa de estabilização econômica em relação a outros, anteriores, foi conseguir acabar com a indexação da economia sem congelamento de preços. (LAMEIRA, 2004)

Ato contínuo, para além do Plano Real, pode-se destacar algumas políticas e mudanças institucionais econômicas vinculadas à nova ordem liberal no Brasil como a quebra dos monopólios estatais do petróleo, telecomunicações e distribuição de gás canalizado em 1995, bem como a ampla delegação de prerrogativas de regulamentação de transações econômicas para o Banco Central e o Conselho Monetário Nacional; formulação do Plano Diretor da Reforma do Estado. Desse cenário até meados de 2002, registram-se também extensas privatizações de empresas federais e estaduais em vários setores, especialmente em serviços e infraestrutura, com ampla participação do capital estrangeiro. (IANONI, 2009)

A partir de 1997, inicia-se o que seria consolidado como Reforma da Gestão Pública em 1998. Neste âmbito surgem as primeiras agências reguladoras, alterando, em definitivo, a forma de intervenção estatal na economia, pavimentando o caminho para a implementação da Lei de Responsabilidade Fiscal, em 2000.

A partir de então, já sob a gestão do Partido dos Trabalhadores, outras mudanças, estritamente voltadas para economia, são arranjadas, como a aprovação da Emenda Constitucional $n^{\circ} 40$ em 2003, que trata do Sistema Financeiro Nacional, a Reforma da Previdência e aprovação da Emenda Constitucional n42 sobre a Reforma Tributária. 
Por fim, leis como as que regulamentam a parceria público-privada, a falência e as micro e pequenas empresas consolidaram o modo de intervenção no mercado nacional, que, se por um lado, buscavam incentivar a economia, por outro deram continuidade à política de elevação da carga tributária, que em 2005 alcançou $37,37 \%$ do PIB, travando a expansão das empresas em solo brasileiro. ${ }^{50}$

Das mudanças destacadas podem perceber-se diversos vieses ideológicos distintos, como cumpre analisar. As primeiras reformas após a implementação do Plano Real possuíam uma natureza mais liberalizante, voltadas à estabilização da economia nacional. A privatização de serviços e a quebra de monopólios nos setores econômicos desembocaram no que se concretizou na reforma da administração pública, retirando o Estado da atuação direta no mercado, possibilitando sua abertura à importação. (RIBEIRO, 2013)

Ademais, pode-se notar que tais políticas liberalizantes não configuram exclusividade desse período específico. O que se manifesta na apreciação da conjuntura brasileira é a incidência pontual e recorrente de políticas de natureza mais ou menos liberal, ainda que por vezes inseridas sob a égide de governos potencialmente orientados por ideologias diversas do próprio liberalismo, como se percebeu no cenário descrito desde o regime militar.

Nesses termos, é forçoso lembrar que, conforme apontado acima, a adaptação de qualquer forma ideológica ao contexto brasileiro sempre passa pelo crivo de nossas cultura e tradição históricas, intimamente ligadas ao patrimonialismo e às relações pessoais, seja na esfera privada, seja na pública. Desse modo, as relações entre o Estado e a economia são dificilmente encaixadas exclusivamente nos termos de maior ou menor controle segundo as ideologias dispostas. Refletem, de fato, uma onipresença do Estado e a dependência da população frente ao mesmo que vem desde nossa história como Colônia.

Em tal contexto, a ideologia libertária no Brasil, ou mesmo outras ideologias de vertentes liberais, tem se manifestado de forma mais incisiva apenas nos últimos anos. Pode-se atribuir tal fato aos resultados vislumbrados com as políticas liberalizantes adotadas na concepção e execução do Plano Real, em especial o controle inflacionário e estabilização econômica alcançada em determinados períodos.

\footnotetext{
50 IANONI, Marcus. Políticas Públicas e Estado: o Plano Real. Lua Nova, São Paulo, n. 78, p. 143-183, 2009.
} 
Enfim, em que pese sua representação no cenário político, as questões de liberdade agora levantadas assumem uma conotação ideológica voltada para as premissas de governos anteriores, e não meramente econômicas, reacendendo o debate sobre princípios e valores ideológicos voltados à persecução da liberdade.

Nesse contexto, as premissas adotadas na seara econômica são agora retomadas no cenário político, desencadeadas, em parte, pelas investigações que têm pontuado os governos brasileiros nos últimos anos, tal como a Operação Castelo de Areia em 2009 e a Operação Lava Jato em 2014. Seu cerne abrange a problemática própria do patrimonialismo anteriormente mencionado, qual seja a confusão entre a esfera pública e privada na gestão, direcionada sempre para manutenção de privilégios.

Ademais, uma vez que o discurso ideológico começa a mudar, inevitavelmente a política econômica, bem como a própria estruturação do Estado, também passam por reformas de adequação, onde a organização vigente pode ser vista como incompatível com a argumentação libertária agora em quadro.

Um dos fomentadores de ideias liberais no país, o Instituto Liberal, foi fundado em 1983, visando, inicialmente, à promoção de princípios como livre mercado e estado mínimo até então estranhos ao debate nacional. O Portal Libertarianismo, fundado já em 2008, propõe-se a tarefa semelhante, buscando tornar o material teórico a respeito do libertarianismo, que, via de regra, encontra-se no idioma inglês, acessível para os brasileiros. Nesse contexto, pontua ${ }^{51}$

Os libertários são comprometidos com a crença de que os indivíduos, e não estados ou grupos de qualquer outro tipo, são ambos ontológica e normativamente primários; que indivíduos tem direitos contra certos tipos de interferência forçosa sobre outros; que a liberdade, entendida como nãointerferência, é a única coisa que pode ser demandada legitimamente dos outros como uma questão legal ou de direito político; que direitos de propriedade contundentes e a liberdade econômica que resulta do reconhecimento consistente, são de importância central na garantia das liberdades individuais; que a ordem social não está em desacordo, mas desenvolve a liberdade individual; que o único uso adequado da coerção é defensivo ou para retificar um erro; que os governos estão sujeitos essencialmente aos mesmos princípios morais que os indivíduos; e que a maior parte dos governos existentes no decorrer da história tem agido inapropriadamente, já que eles tem utilizado a coerção para pilhagem, agressão, redistribuição e outros propósitos além da proteção da liberdade individual.

Outros movimentos de início mais recente, buscaram não só a disseminação das ideias, mas também a inserção dos valores e propostas da liberdade no cenário

${ }^{51} \mathrm{http}: / /$ www.libertarianismo.org/index.php/sobre-2/libertarianismo/ 
político brasileiro. Exemplo disso é a organização apartidária denominada Estudantes Pela Liberdade, fundada em 2008 nos Estados Unidos e trazida ao Brasil em 2010, que busca mobilizar a comunidade estudantil em prol dos ideais libertários por meio de livros e palestras, bem como o Instituto Milenium, fundado em 2005, voltado para divulgação de ideias e soluções em defesa do indivíduo e da liberdade de mercado.

Igualmente militante é o Movimento Brasil Livre (MBL), que, no cenário de insatisfação política patente e generalizada em 2014, surge em defesa do liberalismo e do republicanismo, elencando em seu manifesto objetivos como "imprensa livre e independente, liberdade econômica, separação de poderes, eleições livres e idôneas e fim de subsídios diretos e indiretos para ditaduras".

Na seara político partidária, o Partido Novo surge em 2011 com a função autodeclarada de representar no meio político valores como a liberdade individual, 0 livre mercado e a diminuição da carga tributária e gestão estatal, como cumpre pontuar

- Preservar as liberdades individuais e a propriedade privada em oposição a conceitos coletivistas e ao Estado paternalista.

- Simplificar a complexa legislação e regulamentação, desonerando o pagador de impostos, estimulando a economia e combatendo a corrupção.

- Promover a livre iniciativa com o estímulo a um ambiente empreendedor, estabelecendo regras transparentes, adequando a legislação trabalhista, simplificando a estrutura tributária e priorizando o interesse do consumidor.

Outro difusor das ideias liberais de livre mercado, empreendedorismo e estado mínimo é o Fórum da Liberdade, promovido desde 1988 pelo Instituto de Estudos Empresariais e, reconhecido como o maior espaço de debate político, econômico e social da América Latina. Realizado anualmente, reúne milhares de pessoas, entre estudante e empresários, para discutir a situação político econômica atual, bem como novos rumos para superar os problemas emergentes.

O surgimento de tais movimentos e organizações, especialmente nos últimos oito anos, sugere uma mudança no cenário político brasileiro, sendo esta uma reação ideológica para demonstrar um crescimento de posicionamentos liberais e, paralelamente, uma maior disseminação e consolidação da ideologia libertária.

Um potencial marco do crescimento do libertarianismo em solo brasileiro pode ser vislumbrado a partir das manifestações sociais que marcaram o ano de 2013 e, 
de modo intermitente, levaram à queda do governo Dilma Rousseff em 2016. Apesar de, inicialmente, os movimentos e manifestações terem aparentado caráter apartidário, crítico, de maneira genérica, à ineficiência do Estado brasileiro, foram gradualmente transformadas em críticas cada vez mais virulentas ao governo. Neste contexto, tendo na linha de frente os movimentos supramencionados que representavam na ocasião os princípios do libertarianismo até aqui analisados, como a diminuição do Estado, da regulamentação e benefícios, e, consequentemente, da influência estatal nas liberdades individuais (JARROS, 2016).

Por outro lado, as mesmas manifestações mencionadas podem justificar-se por uma reação apenas direcionada ao meio econômico, onde as consequências do patrimonialismo anteriormente conceituado mostram-se de forma prática no cotidiano nacional. Nessa conjuntura pontua Roberti, 2016:

“... estamos vivendo um momento único para as novas gerações. Desde a estabilização da economia, com o Plano Real, esses jovens estavam acostumados com um país de crescimento constante, melhorias duráveis na condição de vida e acesso a tecnologias jamais imagináveis em épocas anteriores. Agora, pela primeira vez em mais de duas décadas, perceberam seu poder de compra cair abruptamente."

Sob esse prisma, as atuações no cenário de mudança política demonstram-se com a participação efetiva, quando não majoritária, de jovens das mais variadas categorias, "relacionada ao desejo de transformação social e à expectativa de um mundo melhor, mais justo, com menos desigualdades sociais, em que 'as coisas possam estar menos erradas'”52

De todos estes pontos, resta a análise contextual da conjuntura brasileira sob o prisma específico dos conceitos libertários anteriormente estudados. Conforme colocado nas seções anteriores, os libertários defendem o direito individual de cada um à vida, liberdade e propriedade, alheios ao controle do Estado. Nessa perspectiva, percebe-se que as insatisfações sociais se insurgem menos com a coerção propriamente dita do Estado e mais com o patrimonialismo explícito que norteiam as relações público privadas, ou seja, aplicam-se no contexto brasileiro as premissas de natureza libertária, voltadas, contudo, ao combate às interferências do Estado nas liberdades individuais e autonomia privada.

O que se busca nesse esteio é um governo que responda à lei tal como a sociedade, sem valer-se da força para moldar comportamentos, para manipular

52 CASTRO, Lúcia Rabello de. Participação Política E Juventude: Do Mal-Estar À Responsabilização Frente Ao Destino Comum. Revista De Sociologia E Política V. 16, № 30: 253268 Jun. 2008 
interações sociais ou para gerenciar a economia. ${ }^{53}$ Enfim, alheios à criação e manutenção de privilégios na relação entre o Estado e o cidadão.

Em suma, os princípios libertários originalmente defendidos podem ser vislumbrados no discurso ideológico atual, contudo, adaptados às particularidades do contexto brasileiro em que se insere. Em verdade, se originalmente o combate do libertarianismo era contra o totalitarismo e a social democracia, no Brasil as mesmas ideias são apresentadas, só que em oposição a um Estado patrimonial.

A crítica a esse Estado, que confunde público e privado e acaba com a igualdade perante a lei, é essencialmente a mesma oferecida pelo libertarianismo quando buscando garantir as liberdades individuais, restando, contudo, modificada pelo discurso político para que se adapte ao cenário brasileiro atual.

Daqui, cabe uma regressão ao conceito de ideologia adotado na presente pesquisa, onde foi tido como algo essencial à organização social, possibilitando a opção entre diversos valores que norteiam determinados grupos. Mais ainda, atua de forma útil e positiva para o aperfeiçoamento do discurso político, viabilizando tanto a manutenção do sistema vigente como a sua reforma completa.

Nesse esteio, cumpre ressaltar a ausência de hegemonia ideológica vigente, agora ou no passado, uma vez que a pluralidade proporcionada pela democracia, além da própria autonomia da vontade individual e do livre discernimento, termina por estratificar a política e distintas ideologias, que, a depender do contexto social em questão, alternam-se em sua predominância. Desse modo, da mesma forma que se nota um crescimento considerável da ideologia libertária em alguns cenários, também persiste a oposição imediata e ramificações outras, resultado inevitável de uma democracia.

Por tudo exposto, não seria passível afirmar de forma taxativa que o libertarianismo é a única, ou melhor, solução aos problemas enfrentados no Brasil atualmente. $\mathrm{O}$ que se pôde observar ao longo do contexto descrito foi a pluralidade de ideologias que foram aplicadas ao longo dos anos nos mais diversos contextos, e que, a depender da ideologia adotada, os mesmo atos e fatos podem significar de formas diferentes.

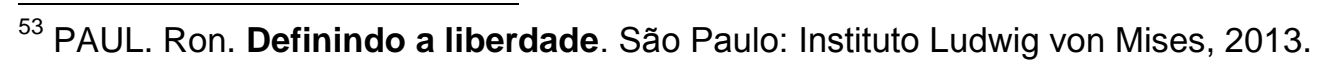




\section{CONSIDERAÇÕES FINAIS}

Durante a realização dessa pesquisa, assumiu-se o desafio de compreender o desenvolvimento do libertarianismo enquanto ideologia, e de que meios e modos esta penetra na organização social e na formação dos discursos políticos em voga, para, ao fim, apreender a aplicação dessa ideologia ao cenário político brasileiro nos últimos anos.

Para tanto, considerou-se o conceito de ideologia como algo essencialmente positivo e necessário à vida social, em especial no campo político, partindo do pressuposto de que surge não apesar do homem ser racional, mas porque ele é racional, ou seja, como uma representação coerente de determinado contexto.

Em um primeiro momento, ainda no momento de revisão bibliográfica buscouse uma compreensão do liberalismo clássico, ponto de partida para análise não só da formação dos ideias e valores voltados à liberdade, mas também para evolução política da sociedade ocidental, como demonstrado no primeiro tópico. Nessa seara, tem-se as ideias de John Locke como princípios norteadores da liberdade individual, colocada sob o tripé do memorável lema de vida, liberdade e propriedade.

A partir desse embasamento teórico, pôde-se compreender melhor a evolução política no Ocidente, limitada, contudo, ao recorte temporal do século XX, onde, compreendidas as guerras e revoltas que modificaram de forma irrevogável o posicionamento político ideológico, vislumbram-se as origens do libertarianismo tal como hoje conhecido.

Nesse ínterim, libertarianismo é tido como uma nova ideologia em favor da liberdade, dissociada, em termos teóricos, das premissas liberais anteriores e suas simplificações e, em termos práticos, das políticas do Estado de bem-estar social e derivados. Aqui compreende-se as ideias colocadas por outros liberais modernos, como as críticas de Hayek ao socialismo, e Mises, que ao defender a liberdade econômica, debruça-se sobre toda gama de direitos individuais a serem preservados.

Em seguida, buscou-se analisar a ideologia libertária no que diz respeito a suas origens no liberalismo clássico e sua evolução no período de guerras, focandose na ideia de liberdade, elemento fulcral de ambas as ideologias em pauta. Tratase, aqui, fundamentalmente, da liberdade individual, alçada no princípio da nãoagressão, da valorização da propriedade privada e da supremacia do indivíduo, 
onde o papel do governo seria apenas o de garantir o respeito a esses pressupostos e a segurança da sociedade.

Para uma maior compreensão da ideologia estudada, seguiu-se uma análise de alguns conceitos básicos de economia, norteados pela incidência, maior ou menor, de preceitos libertários. Tal exame mostrou-se necessário para a compreensão do libertarianismo aplicado ao meio econômico, meio esse onde ele exerce maior influência em seus discursos.

Ato contínuo, então adentrando no ponto fulcral da pesquisa, qual seja a atual conjuntura brasileira, os conceitos de economia então estudados nortearam uma breve análise do marco temporal escolhido para esta pesquisa, que se inicia com a implementação do Plano Real.

Para tanto, foi realizada uma sucinta digressão sobre o contexto em que se inseriu tal reforma, ressaltando como se deu sua real efetivação e quais seus efeitos na economia brasileira e, principalmente, na compreensão das ideologias políticoeconômicas vigentes.

Por fim, em análise concreta das teorias estudadas com o cenário pretendido, fez-se um paralelo entre os conceitos previamente analisados com o cenário político-social brasileiro, levando-se em consideração a apropriação do discurso libertário no cenário nacional e sua conexão com as manifestações que ocorreram em 2013.

Destarte, em análise às perspectivas comparadas, pôde-se, de fato, vislumbrar uma tendência liberalizante no discurso político brasileiro nos últimos anos, demonstrando-se, todavia, que tal tendência pode ser também atribuída às consequências do patrimonialismo presente na construção social e política do Brasil. Ressalta-se ainda que o potencial crescimento do libertarianismo, não se mostra, de forma alguma, homogêneo, sendo que o mesmo cenário fértil a tal ideologia abriga semelhantes e distintas ideologias, que se intensificam e alternam em diferentes contextos, prevalecendo na atual conjuntura os ideais de liberdade, seja ela individual, seja em relação ao Estado.

Resta claro, então que as hipóteses iniciais se confirmaram apenas parcialmente. A primeira, referente ao contexto brasileiro recente se mostrar ambiente propício ao surgimento de uma resposta libertária, obtêm confirmação parcial, na medida em que se percebeu uma conjuntura de insatisfação popular frente a um Estado patrimonialista. Entretanto, frisa-se que, apesar de elementos 
ideológicos em comum, o libertarianismo não aparece como a única, ou mais adequada resposta aos problemas em pauta. Por sua vez, no que diz respeito à segunda hipótese, de fato, pelas organizações e movimentos listados, é possível apontar um crescimento e maior relevância da ideologia libertária, ou ao menos das ideias de liberdade a ela vinculadas. Do mesmo modo, é notável a necessidade de sua adaptação à conjuntura nacional, justamente pelas diferenças marcantes de seu contexto de origem.

Por tudo o exposto, e devido à complexidade do tema, ante aos diversos fatores que devem ser levados em consideração quando da análise de ideologias e a mutabilidade do cenário político adotado, diversas dificuldades se apresentaram ao longo deste trabalho, demonstrando e impossibilidade de um desfecho absoluto no patamar em que se encontra. Por consequência, mostra-se essencial a continuidade do estudo pretendido inicialmente, apronfundando a análise teórica da matéria e sua contextualização necessária com o cenário político, acompanhando, para tanto, suas flutuações e mudanças para melhor percepção do fenômeno ideológico em tela. Do mesmo modo, espera-se que a revisão teórica, assim como as análises e conclusões tentativas empreendidas sirvam de incentivo a novos estudos na área. 


\section{REFERÊNCIAS BIBLIOGRÁFICAS}

AGUIAR, Neuma. Patriarcado, sociedade e patrimonialismo. Soc. estado., Brasília, v. 15, n. 2, p. 303-330, Dec. 2000.

ALTHUSSER, Louis. A parelhos ideológicos de Estado. 10. Ed. Rio de Janeiro: Editora Graal. 2007.

BOAZ, David. Libertarianism: a primer. Washington, DC: Simon \& Schuster, 1998. BOAZ, David. The Libertarian Reader. Washington, DC: Simon \& Schuster, 2015. BOUDON, Raymond. A Ideologia. São Paulo: Editora Atica. 1998

BRESSER-PEREIRA, Luiz Carlos. O Novo Desenvolvimentismo e a Ortodoxia Convencional. São Paulo: São Paulo em Perspectiva, v. 20, n. 3, p. 5-24, jul./set. 2006

CASTRO, Lúcia Rabello de. Participação Política E Juventude: Do Mal-Estar À Responsabilização Frente Ao Destino Comum. Revista De Sociologia E Política V. $16, N^{\circ} 30: 253-268$ Jun. 2008

CHAUI, Marilena. O que é ideologia. Coleção Primeiros Passos. Rio de Janeiro: Editora Brasiliense. 2002.

CLARKE, Simon. Crise do fordismo ou crise da social-democracia?. Lua Nova, São Paulo, n. 24, p. 117-150, Sept. 1991

CONSTANT, Benjamin. Da liberdade dos antigos comparada à dos modernos. Revista Política n.2. 1985.

EAGLETON, Terry. Ideologia. 2.ed. São Paulo: Editora UNESP. 1997.

FAORO, Raymundo. Os Donos do Poder - Formação do Patronato Político Brasileiro. São Paulo, Globo. 2000.

FEIJO, Ricardo Luis Chaves. Uma interpretação do Primeiro Milagre Econômico Alemão (1933-1944). Rev. Econ. Polit., São Paulo , v. 29, n. 2, p. 245-266, June 2009 .

FRANCO, Gustavo H. B. Precisamos falar sobre o capitalismo. Quem move o mundo, 2016.

FRIEDMAN, Milton. Capitalismo e Liberdade. Rio de Janeiro: LTC Editora, 2014. HAYEK, Friedrich A. Direito, Legislação e Liberdade, vol. 1. São Paulo: Visão. 1985.

HAYEK, Friedrich A. O caminho da servidão. 5.ed. Rio de Janeiro: Instituto Liberal, 1990.

HEYWOOD, Anthony. Ideologias Políticas: do liberalismo ao facismo. São Paulo: Atica, 2010.

HOBSBAWM, Eric. A Era dos Extremos. São Paulo: Editora Schwarcz LTDA., 1997 IANONI, Marcus. Políticas Públicas e Estado: o Plano Real. Lua Nova, São Paulo , n. 78, p. 143-183, 2009.

LEFRANC, George. Socialismo Reformista. Lisboa: Circulo dos Leitores, 1974.

LAMEIRA, Valdir de Jesus. Uma revisão sobre economia brasileira e o mercado após o plano real: as mudanças e a evolução do mercado de capitais entre 1995 e 2002. Revista contabilidade e finanças - USP. São Paulo n. 35 pp. 96 - 110, maio/agosto 2004

LOCKE, John. Segundo Tratado sobre o Governo Civil. 3.ed. Petrópolis: Editora Vozes, 2001.

MADISON, James. Federalist Paper n. 10. In: BOAZ, David. The Libertarian Reader. Simon \& Schuster, 2010.

MANKIW, N Gregory. Introdução à Economia. São Paulo: Cengage Learning: 2014 
MILL, John Stuart. Princípios de economia política. São Paulo: Nova Cultural Ltda, 1996.

MILL, John Stuart. Sobre a liberdade. Lisboa: Edições 70 LDA, 2006.

MISES, Ludwig von. As seis lições. 7.ed. São Paulo: Instituto Ludwig von Mises Brasil, 2009.

MISES, Ludwig von. Ação Humana - Um tratado de economia. São Paulo: Instituto Ludwig von Mises Brasil, 2010.

MISES, Ludwig von. Liberalismo segundo a tradição clássica. 2.ed. São Paulo: Instituto Ludwig von Mises, 2010

NOZICK, Robert. Anarquia, Estado e Utopia. Rio de Janeiro: Jorge Zahar Editor Ltda., 1974.

PAIM, Antônio. Agenda teórica dos liberais brasileiros. São Paulo: Massao Ohno Editor, 1997.

PEREIRA, Potyara A. P.. O sentido de igualdade e bem-estar em Marx. Rev. katálysis, Florianópolis, v. 16, n. 1, p. 37-46, June 2013.

PAUL. Ron. Definindo a liberdade. São Paulo: Instituto Ludwig von Mises, 2013.

RAND, Ayn. A Revolta de Atlas. São Paulo: Arqueiro, 2010.

RAWLS, John. Teoria da Justiça. São Paulo: Martins Fontes, 2000.

RICARDO, David. Princípios da economia política e tributação. São Paulo: Nova Cultural Ltda, 1996.

ROTHBARD, Murray N. Por uma nova liberdade: o manifesto libertário. São Paulo: Instituto Ludwig von Mises Brasil, 2010.

ROTHBARD, Murray N. Esquerda e direita: perspectivas para a liberdade. 3.ed. São Paulo: Instituto Ludwig von Mises Brasil, 2010.

RUDIO, Franz Victor. Introdução ao projeto de pesquisa científica. $31^{a}$ ed. Rio de Janeiro: Vozes, 2003

SILVA, Jose Otacílio. A Produção de ideologias políticas segundo Max Weber. Revista Ciências Sociais em Perspectiva.. 2006.

SMITH, Adam. A Riqueza das Nações. São Paulo: Abril Cultural, 1983.

TOCQUEVILLE, Alexis De. A democracia na América. São Paulo: Martins Fontes, 2004.

THOMPSON, John B. Ideologia e cultura moderna. Petrópilis: Editora Vozes. 1990.

VICENTE, MM. História e comunicação na ordem internacional [online]. São Paulo: Editora UNESP; São Paulo: Cultura Acadêmica, 2009

WEBER, Max. A ciência como vocação. 1983. 